\title{
How consistent are health utility values?
}

\section{Pedro L. Ferreira $\cdot$ Lara N. Ferreira}

Luis N. Pereira

Published online: 17 September 2008

(C) Springer Science+Business Media B.V. 2008

\section{Erratum to: Qual Life Res (2008) 17:1031-1042}

DOI 10.1007/s11136-008-9368-8

The last author's affiliation was incorrectly specified in the original publication. The correct list of authors and their affiliations is shown below.

The online version of the original article can be found under doi:10.1007/s11136-008-9368-8.

P. L. Ferreira $(\bowtie)$

Faculty of Economics, University of Coimbra, Coimbra,

Portugal

e-mail: pedrof@fe.uc.pt

P. L. Ferreira · L. N. Ferreira

Centre for Health Studies \& Research, University of Coimbra,

Coimbra, Portugal

L. N. Ferreira · L. N. Pereira

School of Management, Hospitality and Tourism, University of the Algarve, Faro, Portugal 